\title{
PENGARUH PENAMBAHAN ABU BATU DAN SEMEN MORTAR UTAMA TYPE 400 TERHADAP KUAT TEKAN MORTAR STANDAR FC' 4,60 MPa
}

\author{
Asrullah $^{1)}$, Diawarman ${ }^{2)}$ Ricky Meiza ${ }^{3)}$ \\ ${ }^{1), 2)}$ Dosen tetap YPTP pada Prodi. T. Sipil Universitas Palembang \\ ${ }^{3)}$ ASN PUPR Provinsi Sumatera Selatan \\ ${ }^{1)}$ Email : Asrull66@yahoo.co.id
}

\begin{abstract}
Abstrak
Perkembangan konstruksi sangat cepat dan sangat mendukung pembangunan, tidak hanya pada daerah perkotaan tetapi juga pada daerah-daerah yang terpencil. Adapun konstruksi bangunan gedung, jalan, jembatan, dermaga dan sebagainya tidak lepas dari mortar salah satu bahan pendukung bangunan tersebut. Penelitian mortar adalah salah satu bagian yang terlepas dari perkembangan konstruksi yang ada dan juga sangat erat hubungannya dengan pembangunan-pembangunan yang sedang berjalan seperti pembangunan jalan, jembatan, gedung, dermaga dan sebagainya. Tujuan penelitian adalah untuk mengetahui pengaruh penambahan Abu Batu dan semen Mortar Utama Type 400 terhadap kuat tekan mortar. Manfaat penelitian adalah untuk memberikan inovasi pemakaian material sebagai gambaran dalam komposisi campuran mortar. Metode yang digunakan dalam penelitian ini adalah mengacu kepada SNI 03-6825-2002. Kesimpulan dari penelitian ini adalah kuat tekan mortar Standar (MS) sebesar 4,67 MPa memenuhi standar yang direncanakan sebesar 4,60 MPa, kuat tekan mortar tertinggi dengan penambahan Abu Batu MAB $10 \%$ sebesar 5,85 MPa, kuat tekan mortar tertinggi dengan penambahan Semen Mortar Utama type 400 MMU 10\% sebesar 6,07 MPa. Persamaan Regresi sederhana Pengaruh Penambahan Abu Batu terhadap Kuat Tekan mortar y $=0,418 x+4,285$, dengan $R^{2}=0,949$, Sedangkan persamaan regresi sederhana pengaruh penambahan Semen Mortar Utama Type 400 terhadap Kuat Tekan mortar $y=0,428 x+4,59$, dengan $R^{2}=0,694$.
\end{abstract}

Kata Kunci : Kuat tekan, mortar, abu batu, semen mortar utama type 400 Regresi Linier

\begin{abstract}
Construction development is very fast and very supportive of development, not only in urban areas but also in remote areas. The construction of buildings, roads, bridges, docks and so on cannot be separated from mortar, one of the building's supporting materials. Mortar research is an integral part of the development of existing construction and is also closely related to ongoing developments such as the construction of roads, bridges, buildings, docks and so on. The purpose of this study was to determine the effect of adding Stone Ash and Type 400 Main Mortar cement to the compressive strength of the mortar. The benefit of the research is to provide innovation in the use of materials as an illustration in the composition of the mortar mixture. The method used in this research is referring to SNI 03-6825-2002. The conclusion of this study is that the standard mortar compressive strength (MS) of 4.67 MPa meets the planned standard of 4.60 MPa, the highest compressive strength of mortar with the addition of $10 \%$ MAB Stone Ash is $5.85 \mathrm{MPa}$, the highest compressive strength of mortar with the addition of Cement Mortar Utama type 400 MMU 10\% of 6.07 MPa. Simple Regression Equation Effect of Addition of Stone Ash on Compressive Strength of mortar $y=0.418 x+4.285$, with $R^{2}=$ 0.949, while the simple regression equation of effect of addition of Cement Mortar Type 400 on Compressive Strength of mortar $y=0.428 x+4.59$, with $\mathrm{R}^{2}=0.694$.
\end{abstract}

Keywords: Compressive strength, mortar, stone ash, main cement mortar type 400, Linear Regression 


\section{PENDAHULUAN}

Perkembangan konstruksi sangat cepat dan sangat mendukung pembangunan, tidak hanya pada daerah perkotaan tetapi juga pada daerah-daerah yang terpencil. Adapun konstruksi bangunan gedung, jalan, jembatan, dermaga dan sebagainya tidak lepas dari mortar salah satu bahan pendukung bangunan tersebut. Penelitian mortar adalah salah satu bagian yang terlepas dari perkembangan konstruksi yang ada dan juga sangat erat hubungannya dengan pembangunan-pembangunan yang sedang berjalan seperti pembangunan jalan, jembatan, gedung, dermaga dan sebagainya.

Mortar terbentuk dari bahanbahan semen, pasir dan air tanpa adanya bahan tambahan lain. Semen dibuat dari semen hidrolis yang dihasilkan dengan menghaluskan klinker yang terutama terdiri dari silikat-silikat kalsium yang bersifat hidrolis ditambah dengan bahan yang mengatur waktu ikat. Bersifat hidrolis berarti memerlukan air agar dapat terjadi reaksi kimia pada proses hidrasi. Semen bila diaduk dengan air akan membentuk pasta semen, sedangkan jika diaduk dengan air kemudian ditambah pasir akan menjadi mortar semen. Fungsi semen adalah untuk merekatkan butiran-butiran agregat agar terjadi suatu massa yang kompak/padat selain itu juga mengisi rongga-rongga diantara butiran agregat

Perusahaan industri batu belah banyak dibutuhkan dalam kosntruksi, dari produksi batu belah dengan berbagai varian ukuran akan menghasilkan limbah yang disebut limbah abu batu. Abu batu sangatlah banyak dan kurang diminati sebagai bahan material [2]. Dari masalah tersebut limbah abu batu diangkat dalam penelitian ini untuk memberikan inovasi sebagai bahan tambah material konstruksi yang baik, berupa penggunaan material limbah abu batu sebagai subtitusi dari agregat pasir alami pada campuran mortar dengan penambahan semen Mortar Utama.

Dalam perkembangan sekarang ini banyak cara untuk meningkatkan kuat tekan mortar sehingga sangat membutuhkan campuran mortar dari material lain. Dalam penelitian ini penulis mencoba menambah material yang berupa abu batu dan semen Mortar Utama dengan harapan adanya peningkatan kuat tekan mortar dengan komposisi tertentu. Abu batu dan Abu batu merupakan hasil penggerusan dari produksi batu pecah. Abu batu merupakan abu yang mengandung banyak silika, alumina dan mengandung senyawa alkali, besi, dan kapur walaupun dalam kadar yang rendah. Dari setiap daerah, komposisi abu batu digunakan dalam adukan beton terutama untuk memperbaiki sifat dari beton. Pemakaian abu batu dapat menghemat pemakaian semen. Abu batu mengandung senyawa silika yang sangat halus yang bersifat amorf sehingga mampu mengeras bila dicampur dengan semen. Senyawa yang terjadi. antara silika amorf dan kapur adalah senyawa silikat kalsium yang sukar larut dalam air. Kemampuan pengerasan dari abu batu karena adanya bagian-bagian silika amorf yang halus.

Semen Mortar atau biasa disebut semen instan atau mortar instan adalah bahan bangunan berbahan dasar semen, pasir, filler, dan additive khusus yang diformulasi khusus sesuai dengan fungsi dan kegunaan masingmasing jenis. Produk mortar bersifat instan atau siap pakai, penggunaannya tidak perlu lagi ditambahkan bahan material lain, cukup diaduk dengan air secukupnya dan langsung dipalikasikan. Semen instan atau semen mortar ini menjadi bahan bangunan alternatif pengganti adukan semen-pasir konvensional, yang memiliki banyak keunggulan yang lebih praktis, berkualitas, dan efisien [3].

\section{KAJIAN PUSTAKA 2.1. Mortar}

Pengertian mortar adalah adukan yang terdiri dari pasir, bahan perekat dan air. Bahan perekat dapat berupa tanah liat, kapur, maupun semen. Bila tanah yang dipakai sebagai bahan perekat disebut mortar lumpur (mud mortar), bila kapur yang dipakai sebagai bahan perekat disebut mortar kapur, dan bila semen yang dipakai sebagai bahan perekat maka disebut mortar semen. Pasir berfungsi sebagai bahan pengisi (bahan yang direkat).

Fungsi utama mortar adalah menambah lekatan dan ketahanan ikatan dengan bagianbagian penyusun suatu konstruksi. Kekuatan 
mortar tergantung pada kohesi pasta semen terhadap partikel agregat halusnya. Mortar mempunyai nilai penyusutan yang relatif kecil. Mortar harus tahan terhadap penyerapan air serta kekuatan gesernya dapat memikul gaya-gaya yang bekerja pada mortar tersebut. Jika penyerapan air pada mortar terlalu besar/cepat, maka mortar akan mengeras dengan cepat dan kehilangan ikatan adhesinya [4].

\subsection{Air}

Air diperlukan pada pembuatan beton untuk memicu proses kimiawi semen, membasahi agregat dan memberikan kemudahan dalam pekerjaan beton. Air yang dapat diminum umumnya dapat digunakan sebagai campuran beton. Air yang mengandung senyawa-senyawa yang berbahaya, yang tercemar garam, minyak, gula atau bahan kimia lainnya bila dipakai dalam campuran beton akan menurunkan kualitas beton, bahkan dapat mengubah sifat-sifat beton yang dihasilkan [5].

\subsection{Agregat Halus}

Agregat didefinisikan sebagai material granular misalnya pasir, kerikil, batu pecah, dan kerak tungku besi yang dipakai bersama-sama dengan suatu media pengikat untuk membentuk mortar atau beton semen hidrolik atau adukan. Agregat halus disebut pasir, baik berupa pasir alami yang diperoleh langsung dari sungai atau tanah galian, atau dari hasil pemecahan batu. Agregat yang butirbutirnya lebih kecil dari 1,2 $\mathrm{mm}$ disebut pasir halus, sedangkan butir-butir yang lebih kecil dari $0,075 \mathrm{~mm}$ disebut silt, dan yang lebih kecil dari 0,002 $\mathrm{mm}$ disebut clay.

\subsection{Semen Mortar Utama Type 400 \\ Semen Mortar Utama (MU) di} produksi oleh PT Cipta Mortar Utama yang merupakan perusahaan nasional terbesar dan pertama yang memproduksi semen instan siap pakai (premixed mortar) dengan menggunakan teknologi modern yang dikenal dengan merek MORTAR UTAMA (MU), Fungsi utama mortar adalah menambah lekatan dan ketahanan ikatan dengan bagian-bagian penyusun suatu konstruksi. Bahan pengisi (filler) yang terkandung didalamnya Guna meningkatkan kepadatan serta mengurangi porositas bahan adukan, sedangkan Bahan tambah (additive) yang terkandung didalam adalah Bahan larut air yang berguna untuk meningkatkan kelecakan (konsistensi), daya ikat, water retention, keawatan \& kekuatan [6].

\subsection{Abu Batu}

Abu batu merupakan hasil penggerusan dari produksi batu pecah. Abu batu merupakan abu yang mengandung banyak silika, alumina dan mengandung senyawa alkali, besi, dan kapur walaupun dalam kadar yang rendah. Dari setiap daerah, komposisi abu batu digunakan dalam adukan beton terutama untuk memperbaiki sifat dari beton. Pemakaian abu batu dapat menghemat pemakaian semen. Abu batu mengandung senyawa silika yang sangat halus yang bersifat amorf sehingga mampu mengeras bila dicampur dengan semen. Senyawa yang terjadi. antara silika amorf dan kapur adalah senyawa silikat kalsium yang sukar larut dalam air. Kemampuan pengerasan dari abu batu karena adanya bagian-bagian silika amorf yang halus [7]. Dalam penelitian in digunakan Abu Batu di Stone Cruser PT. Komba Mahaka Utama Oku Timur.

\subsection{Perencanaan Campuran Mortar}

Seluruh material untuk benda uji dilakukan pengujian karakteristik sesuai dengan standar yang berlaku. Perbandingan bahanbahan kering dalam mortar adalah 1 bagian berat semen dan 2,75 bagian berat pasir standar. Faktor air semen (w/c) adalah 0,485 untuk semua jenis semen portland dengan flow $110 \pm 5$. Campuran mortar berpedoman pada Standard ASTM C109-93, dengan perincian bahan untuk 6 sampel dibutuhkan semen 500 gram, pasir 1375 gram dan air 242 $\mathrm{ml}[8]$.

\subsection{Analisa Regresi Sederhana}

Analisa regresi linier sederhana dilakukan untuk memperoleh suatu model regresi yang menggambarkan hubungan antara satu variabel bebas (penambahan Abu Batu) dan suatu variabel terikat (kuat tekan beton) [9]. Dalam penelitian ini yang menjadi variabel bebas (X) adalah penambahan Abu Batu, sedangkan variabel terikat $(\mathrm{Y})$ adalah kuat tekan beton. 


\section{METODOLOGI PENELITIAN}

Penelitian ini merupakan suatu eksperimen (percobaan) di laboratorium Jurusan Teknik Sipil Fakultas Teknik Universitas Palembang. yang dilakukan untuk mengetahui pengaruh penambahan Abu Batu dan Semen Mortar Utama Type 400 terhadap kuat tekan mortar.. Garis besar penelitian adalah meliputi kegiatankegiatan sebagai berikut :

1. Analisa karakteristik bahan penyusun mortar

2. Rancangan Campuran Mortar

3. Benda Uji di buat dalam bentuk mortar ukuran $50 \mathrm{~mm}$ x $50 \mathrm{~mm}$ x 50mm metode SNI 03-6825-2002.

4. Mortar di buat dengan beberapa komposisi campuran yaitu :

- Mortar Standar (MS)

- Mortar dengan penambahan Abu Batu (MAB) 5\%,7,5\% dan 10\% dari berat pasir

- Mortar dengan penambahan semen Mortar Utama Type 400 (MMU) $5 \%, 7,5 \%$ dan $10 \%$ dari berat pasir

5. Perawatan benda uji

Pengujian kuat tekan mortar seluruh komposisi campuran pada umur 7,14, 21 dan 28 hari

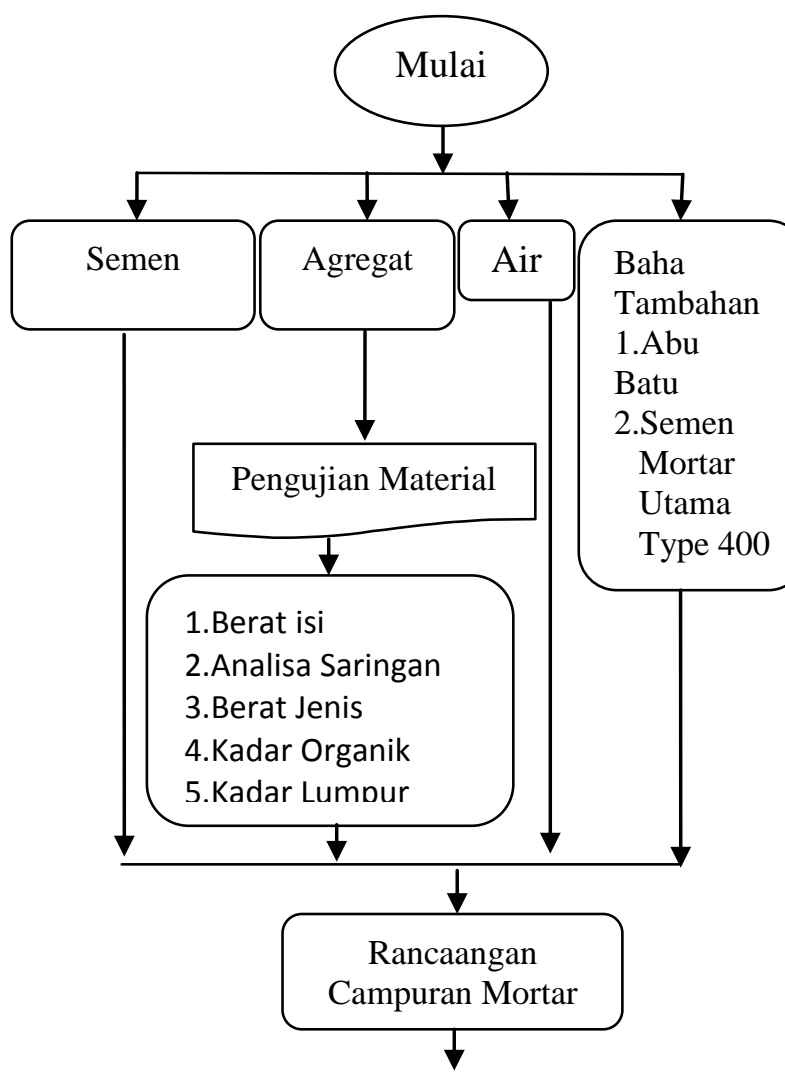

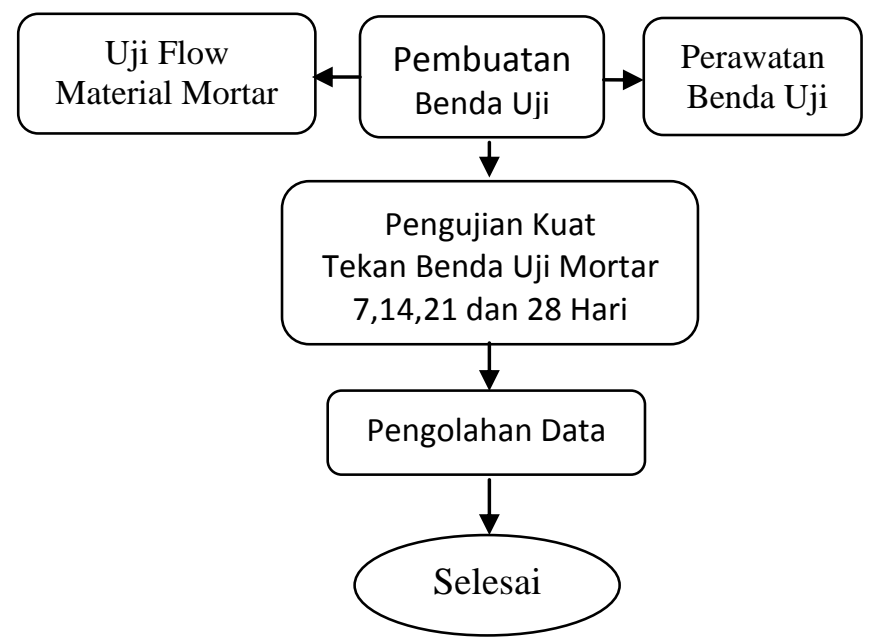

Gambar 3.1. Bagan Alir Penelitian

IV. HASIL DAN PEMBAHASAN

4.1. Kebutuhan Material Untuk Campuran Mortar

Kebutuhan material unntuk campuran mortar disajikan dalam tabel 4.1. berikut ini.

Tabel 4.1. Kebutuhan Material Pada

Seluruh Komposisi Mortar Untuk 6 Sampel

\begin{tabular}{|c|c|c|c|c|c|}
\hline Kode Mortar & $\begin{array}{l}\text { Semen } \\
\text { (gram) }\end{array}$ & $\begin{array}{l}\text { Pasir } \\
\text { (gram) }\end{array}$ & $\begin{array}{l}\text { Air } \\
(\mathrm{ml})\end{array}$ & $\begin{array}{c}\text { Abu Batu } \\
\text { (gram) }\end{array}$ & $\begin{array}{l}\text { Semen } \\
\text { MU } 400 \\
\text { (gram) }\end{array}$ \\
\hline MS & 500 & 1375 & 242 & - & - \\
\hline MAB 5\% & 500 & 1306,25 & 242 & 68,75 & - \\
\hline MAB 7,5\% & 500 & 1271,875 & 242 & 103,125 & - \\
\hline MAB $10 \%$ & 500 & 1237,5 & 242 & 137,50 & - \\
\hline MMU 5\% & 500 & 1306,25 & 242 & - & 68,75 \\
\hline MMU 7,5\% & 500 & 1271,875 & 242 & - & 103,125 \\
\hline MMU 10\% & 500 & 1237,5 & 242 & - & 137,50 \\
\hline
\end{tabular}

\subsection{Hasil Pengujian Kuat Tekan Mortar}

Data hasil penelitian setelah dilakukan pengujian kuat tekan dengan menggunakan rumus $f c^{\prime}=\mathrm{P} / \mathrm{A}$ pada masing-masing variasi mortar yaitu mortan Standar (MS), mortar dengan penambahan Abu Batu dari berat pasir (MAB 5\%, MAB 7,5\%, MAB 10\%), mortar dengan penambahan Semen Mortar Utama 
Type 400 dari berat pasir (MMU 5\%, MMU 7,5\%, MMU 10\%) seperti gambar berikut ini.

\subsubsection{Kuat Tekan Mortar Standar (MS)}

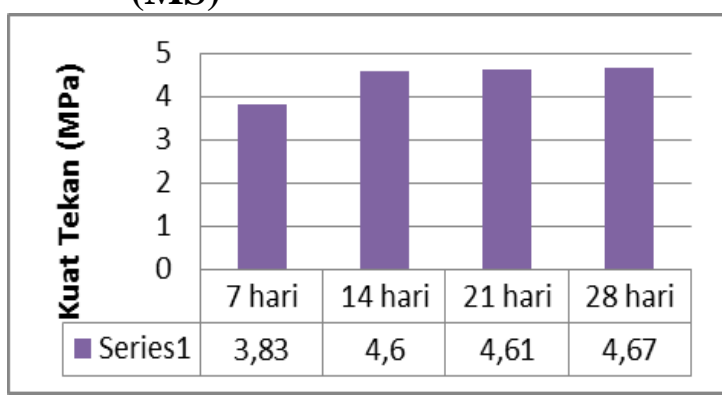

\section{Gambar 4.1. Kuat Tekan Mortar Standar (MS)}

Dari gambar 4.1 kuat tekan mortar standar (MS) untuk umur 7,14,21 dan 28 hari terjadi kenaikan yaitu 3,83 MPa untuk umur 7 hari, 4,60 MPa untuk umur 14 hari, 4,61 untuk 21 hari dan 4,67 MPa untuk umur 28 hari. Bila di lihat syarat yang berlaku untuk kuat tekan mortar standar memenuhi persyaratan yaitu minimal 4,60 Mpa untuk umur 28 hari.

\subsubsection{Kuat Tekan Mortar Dengan Penambahan Abu Batu 5\% (MAB 5\%)}

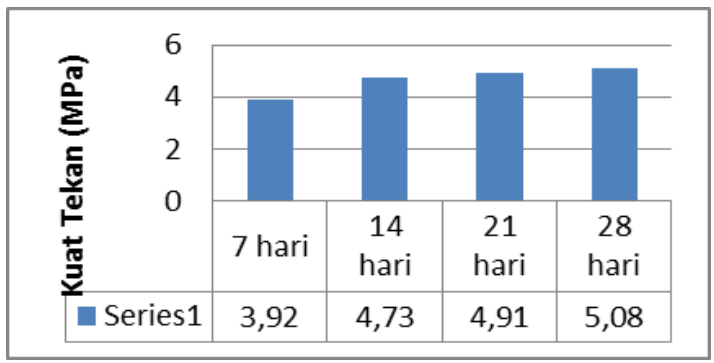

\section{Gambar 4.2. Kuat Tekan Mortar Abu Batu 5\% (MAB5\%)}

Dari gambar 4.2 kuat tekan mortar standar dengan penambahan Abu Batu 5\% (MAB 5\%) untuk umur 7,14,21 dan 28 hari terjadi kenaikan yaitu 3,92 MPa untuk umur 7 hari, 4,73 MPa untuk umur 14 hari, 4,91 untuk 21 hari dan 5,08MPa untuk umur 28 hari. Bila di lihat nilai kuat tekan mortar umur 28 hari untuk MAB 5\% terjadi peningkatan dari kuat tekan mortar standar (MS) 4,67 MPa atau sebesar 8,071\%.

\subsubsection{Kuat Tekan Mortar Dengan Penambahan Abu Batu 7,5\% (MAB 7,5\%)}

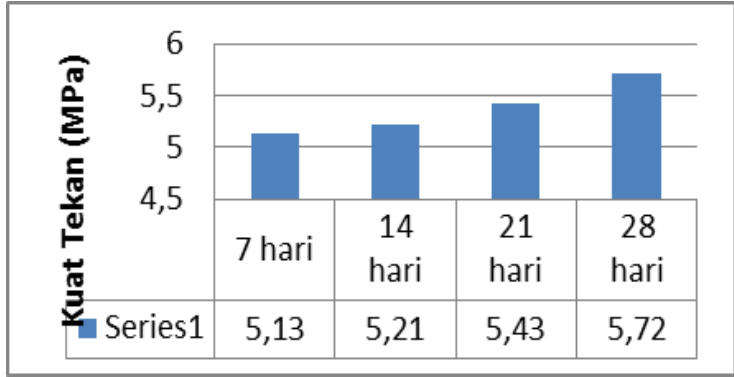

Gambar 4.3. Kuat Tekan Mortar Dengan Penambahan Abu Batu 7,5\% (MAB 7,5\%)

Dari gambar 4.3 kuat tekan mortar standar dengan penambahan Abu Batu 7,5\% (MAB 7,5\%) untuk umur 7,14,21 dan 28 hari terjadi kenaikan yaitu 5,13 MPa untuk umur 7 hari, 5,21 MPa untuk umur 14 hari, 5,43 untuk 21 hari dan 5,72 MPa untuk umur 28 hari. Bila di lihat nilai kuat tekan mortar umur 28 hari untuk MAB 7,5\% terjadi peningkatan dari kuat tekan mortar dengan penambahan Abu Batu 5\% (MAB 5\%) 5,08 MPa atau sebesar $11,19 \%$.

\subsubsection{Kuat Tekan Mortar Dengan Penambahan Abu Batu 10\% (MAB 10\%)}

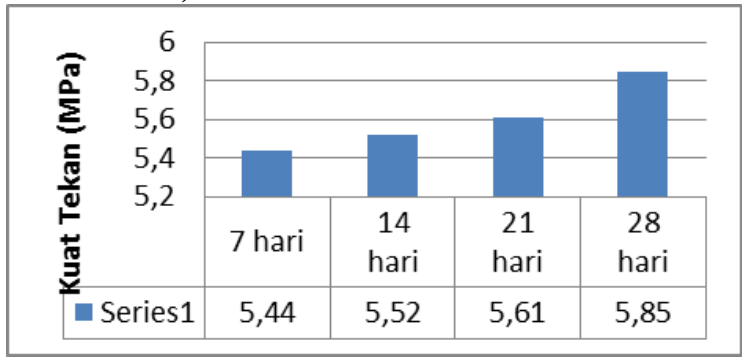

Gambar 4.4. Kuat Tekan Mortar Dengan Penambahan Abu Batu 10\% (MAB 10\%)

Dari gambar 4.4 kuat tekan mortar standar dengan penambahan Abu Batu $10 \%$ (MAB 10\%) untuk umur 7,14,21 dan 28 hari terjadi kenaikan yaitu 5,44 MPa untuk umur 7 hari, 5,52 MPa untuk umur 14 hari, 5,61 untuk 21 hari dan 5,85 MPa untuk umur 28 hari. Bila di lihat nilai kuat tekan mortar umur 28 hari untuk MAB $10 \%$ terjadi peningkatan dari kuat tekan mortar dengan penambahan $\mathrm{Abu}$ Batu 7,5\% (MAB 7,5\%) 5,72 MPa atau sebesar $2,27 \%$. 


\subsubsection{Kuat Tekan Mortar Dengan Penambahan Semen Mortar Utama Type $4005 \%$ (MMU 5\%)}

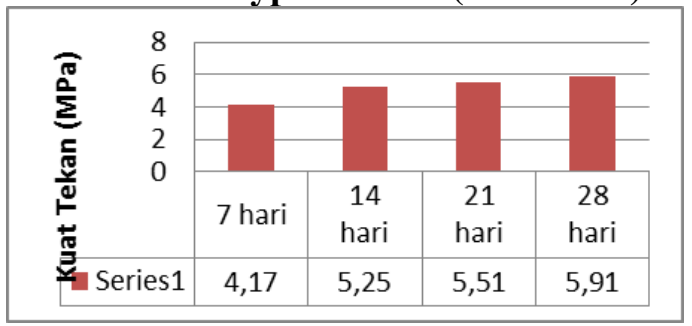

Gambar 4.5. Kuat Tekan Mortar Dengan Penambahan Semen Mortar Utama Type $4005 \%$ (MMU 5\%)

Dari gambar 4.5 kuat tekan mortar dengan penambahan semen Mortar Utama type $4005 \%$ (MMU 5\%) untuk umur $7,14,21$ dan 28 hari terjadi kenaikan yaitu 4,17 MPa untuk umur 7 hari, 5,25 $\mathrm{MPa}$ untuk umur 14 hari, 5,51 MPa untuk 21 hari dan 5,91 MPa untuk umur 28. Nilai ini lebih besar dari nilai kuat tekan Mortar Standar (MS) 4,67 MPa dan lebih besar dari nilai kuat tekan mortar dengan penambahan Abu Batu 5\% (MAB 5\%) 5,08 MPa untuk umur 28 hari.

\subsubsection{Kuat Tekan Mortar Dengan Penambahan Semen Mortar Utama Type $400 \quad 7,5 \%$ (MMU $7,5 \%)$}

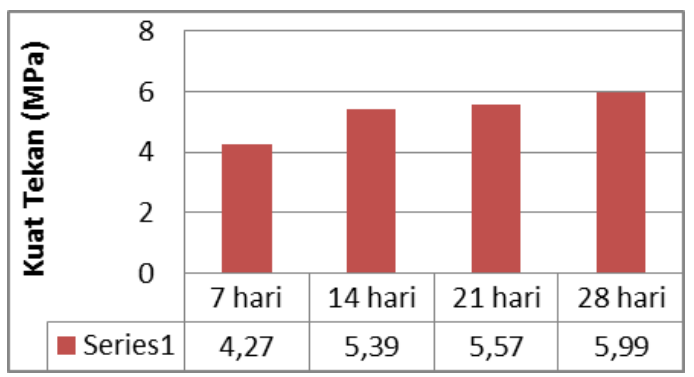

\section{Gambar 4.6. Kuat Tekan Mortar Dengan Penambahan Semen Mortar Utama Type 400 7,5\% (MMU 7,5\%)}

Dari gambar 4.6 kuat tekan mortar dengan penambahan semen Mortar Utama type $4007,5 \%$ (MMU 7,5\%) untuk umur $7,14,21$ dan 28 hari terjadi kenaikan yaitu 4,27 $\mathrm{MPa}$ untuk umur 7 hari, 5,39 $\mathrm{MPa}$ untuk umur 14 hari, 5,57 MPa untuk 21 hari dan 5,99 MPa untuk umur 28. Nilai kuat tekan umur 28 hari lebih besar dari nilai kuat tekan Mortar dengan penambahan semen Mortar Utama type 400 5\% (MMU
5\%) 5,91 atau $1,34 \%$.

\subsubsection{Kuat Tekan Mortar Dengan Penambahan Semen Mortar Utama Type 400 10\% (MMU 10\%)}

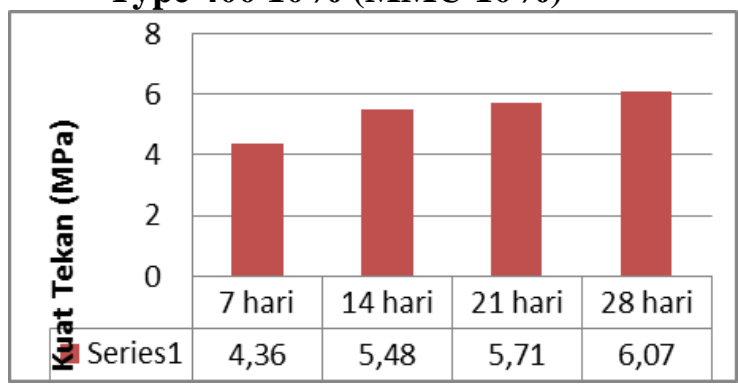

Gambar 4.7. Kuat Tekan Mortar Dengan Penambahan Semen Mortar Utama Type $40010 \%$ (MMU $10 \%$ )

Dari gambar 4.7 kuat tekan mortar dengan penambahan semen Mortar Utama type $40010 \%$ (MMU 10\%) untuk umur 7,14,21 dan 28 hari terjadi kenaikan yaitu 4,36 $\mathrm{MPa}$ untuk umur 7 hari, 5,48 $\mathrm{MPa}$ untuk umur 14 hari, 5,71 MPa untuk 21 hari dan 6,07 $\mathrm{MPa}$ untuk umur 28. Nilai kuat tekan umur 28 hari lebih besar dari nilai kuat tekan Mortar dengan penambahan semen Mortar Utama type 400 7,5\% (MMU 7,5\%) 5,99 atau 1,32\%.

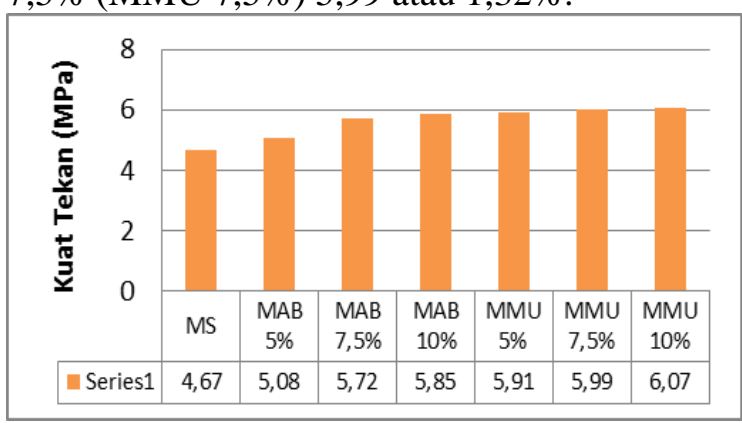

Gambar 4.8. Kuat Tekan Mortar Standar (MS) Mortar Abu Batu (MAB) dan Mortar Semen Mortar Utama Type 400 (MMU) pada Umur 28 hari

Bila dilihat data pada gambar 4.8 secara keseluruhan nilai kuat tekan terjadi kenaikan. Nilai kuat tekan umur 28 hari untuk mortar standar (MS) sebesar 4,67 MPa, untuk nilai kuat tekan mortar dengan penambahan Abu Batu (MAB) terbesar terjadi di persentase penambahan 10\% (MAB 10\%) yaitu sebesar sebesar 5,85 MPa atau sebesar 20,17\% dari nilaimkuat tekan mortar standar (MS). Nilai kuat tekan pada umur 28 hari untuk Mortar dengan penambahan semen Mortar Utama type 400 yang terbesar terjadi pada komposisi $10 \%$ 
(MMU) 10\% yaitu 6,07 MPa atau sebesar $3,62 \%$ dari nilai kuat tekan mortar dengan penambahan Abu Batu 10\% (MAB 10\%).

\subsection{Model Hubungan Regresi Linier Sederhana}

Analisa regresi linier sederhana dilakukan untuk memperoleh suatu model regresi yang menggambarkan hubungan antara suatu variabel bebas (X) (penambahan abu batu dan Semen Mortar Utama Type 400) dan suatu variabel terikat (Y) kuat tekan Mortar. Hasil Analisa regresi disajikan pada gambar 4.9 dan 4.10 berikut ini.
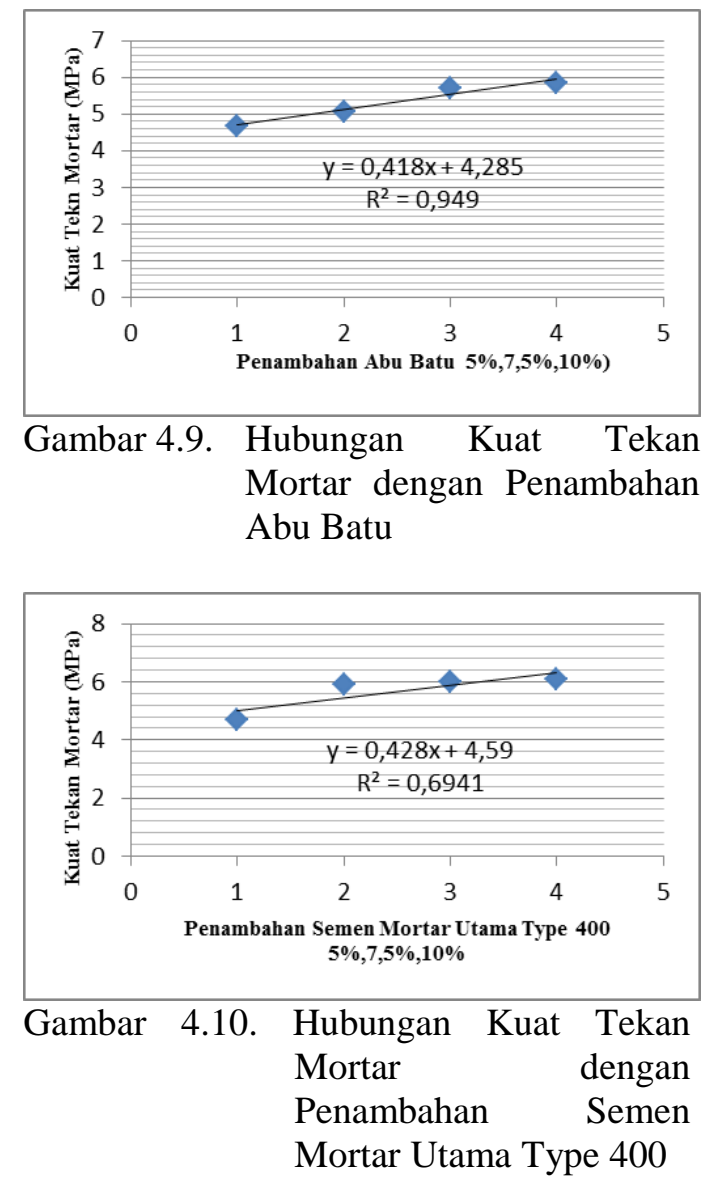

Model regresi pada Gambar 4.9 adalah regresi linier sederhana yang merupakan hubungan antara nilai kuat Mortar dengan penambahan Abu Batu dengan persamaan $y=0,418 x+4,285$. Dari persamaan ini terlihat bahwa nilai positif Asrullah dalam [9] pada koefisien regresi menunjukkan angka kenaikan variabel terikat $(\mathrm{Y})$ yang didasarkan pada variabel bebas (X). Artinya jika penambahan Abu
Batu meningkat, maka akan menyebabkan peningkatan nilai kuat tekan mortar.

Selanjutnya menurut Asrullah dalam [9] koefisien determinasi $R^{2}$ bernilai 0,949 , berarti memeliki keterkaitan yang kuat antara penambahan Abu Batu dan nilai kuat tekan mortar. Selain itu koefisien tersebut memperlihatkan bahwa pengaruh penambahan Abu Batu terhadap nilai kuat tekan mortar sebesar 94,90\%.

Model regresi pada Gambar 4.10 adalah regresi linier sederhana yang merupakan hubungan antara nilai kuat tekan mortar dengan penambahan Semen Mortar Utama Type 400 dengan persamaan $y=0,428 x+4,59$. Dari persamaan ini terlihat bahwa nilai positif Asrullah [9] pada koefisien regresi menunjukkan angka peningkatan variabel terikat (Y) yang didasarkan pada variabel bebas (X). Artinya jika penambahan Semen Mortar Utama Type 400 meningkat, maka akan menyebabkan peningkatan nilai kuat tekan mortar. Selanjutnya menurut Asrullah dalam [9] koefisien determinasi $\mathrm{R}^{2}$ bernilai 0,694 , berarti memeliki keterkaitan yang tidak terlalu kuat antara penambahan Semen Mortar Utama Type 400 dan nilai kuat tekan mortar. Selain itu koefisien tersebut memperlihatkan bahwa pengaruh penambahan Semen Mortar Utama Type 400 terhadap nilai kuat tekan mortar sebesar $69,40 \%$.

\section{KESIMPULAN DAN SARAN}

\section{A. Kesimpulan}

Dari hasil penelitian ini dapat disimpulkan sebagai berikut.

1. Nilai kuat tekan mortar Standar sebesar 4,67 MPa memenuhi standar perencanaan yaitu 4,60 MPa.

2. Nilai kuat tekan mortar dengan penambahan abu batu terbesar yaitu $10 \%$ sebesar 5,85 MPa

3. Nilai kuat tekan mortar dengan penambahan Semen Mortar Utama Type 400 terbesar yaitu $10 \%$ sebesar 6,09 MPa

4. Persamaan Regresi sederhana Pengaruh Penambahan Abu Batu terhadap Kuat Tekan mortar $y=0,418 x+4,285$, dengan $\mathrm{R}^{2}=0,949$

5. Persamaan Regresi sederhana Pengaruh Penambahan Semen Mortar Utama Type 400 terhadap Kuat Tekan mortar

$$
y=0,428 x+4,59 \text {, dengan } R^{2}=0,694
$$




\section{B. Saran-Saran}

Dari hasil yang ada, maka peneliti memberikan saran-saran sebagai berikut :

1. Lakukan penelitian lanjutan

2. Dalam penelitian lanjutan lakukan dengan penambahan persentase Abu Batu dan Semen Mortar Utama Type 400 sehingga diketahui batas maksimum terjadinya peningkatan kuat tekan.

\section{DAFTAR PUSTAKA}

[1] Tjokrodimulyo, K., 2000, Pengujian Mekanik Laboratorium Beton Pasca Bakar, Yogyakarta

[2] Triaswati M.N. ${ }^{1, a)}$, Didik Harijanto', Boedi Wibowo ${ }^{1)}$ \& Wahyu Ismoyo $^{1)}$ Penggunaan Abu Batu untuk Mengurangi Agregat Pasir Alami pada Campuran Beton dengan Penambahan Zat Additive Type D Departemen Teknik Infrastruktur Sipil, Fakultas Vokasi, (ITS). Surabaya.

[3] https://www.supermix.co.id/mengenallebih-jauh-semen-mortar/ diakses 11 September 2020

[4] SNI-03-6882-2002 Spesifikasi Mortar Untuk Pekerjaan Pasangan Badan Standarisasi Nasional ICS 27.180

[5] SNI-03-6825-2002 Metode Pengujian Kekuatan Tekan Mortar Semen Portland Untuk Pekerjaan Sipil Badan Standardisasi Nasional ICS 27.180

[6] http://ptprabuagungperkasa.indonetwork .co.id/4534233/semen-mortarutama-mu.htm di akses 11 September 2020

[7] https://jayawan.com/jual-abu-batu di akses 11 September 2021

[8] Standar ASTM C 109-93

[9] Asrullah and A Mulyadi, 2017. A Study on the Use of Mortar Utama Cement Type 420 as Concrete Admixture. International Conference on Innovative Research ICIR EUROINVENT 2017 IOP Publishing IOP Conf. Series: Materials Science and Engineering $209 \quad$ (2017) 012088 doi:10.1088/1757899X/209/1/012088.pp. 